the euhemeristic views of the late Sir A. Lyall, which regard most of the gods of Hinduism as deified men, are fully accepted. The mana of Dr. Marett resolves itself into a development from relic worship, and his dogma that religion develops from the undifferentiated to the differentiated is criticised on the ground of the complexity of savage society, and in particular its highly developed system of relationship.

It would be premature to discuss these positions, which are still the subject of acute controversy, and the forces now on the defensive may be in a position to make a successful counterattack. This much may be said: while Prof. Ridgeway has doubtless succeeded in proving that

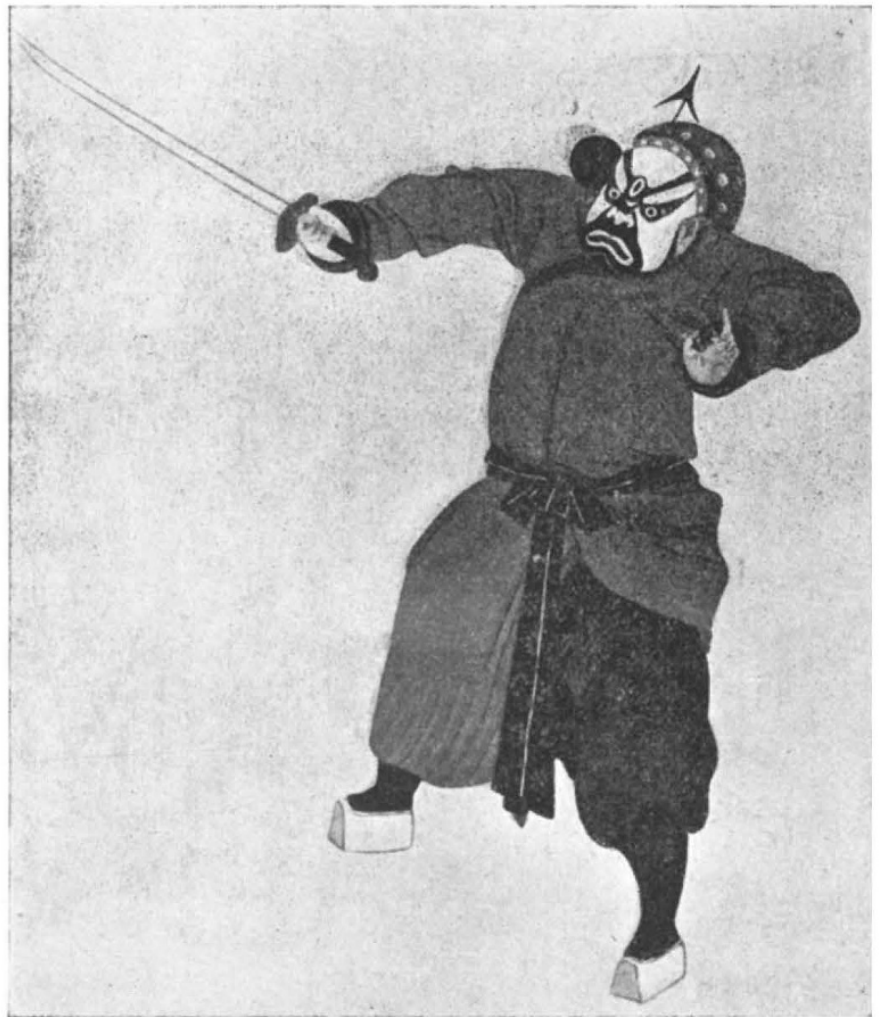

Fig. 2.- The Buffoon (Tchou). From "The Dramas and Dramatic Dances of NonEuropean Races."

the cult of the dead has exercised potent influence on the development of drama--indeed, his leading opponent, Prof. Murray, admits that "it can be shown that every extant tragedy contains somewhere towards the end the celebration of a tabu tomb"-many will hesitate to refer such a complex as dance and drama throughout the world to a single concept; and, to take India alone, Sir A. Lyall's view, which excludes the cult of spirits other than human, leaves unexplained the devotion to Siva, who was in origin a storm god, later developed into a deity of fertility, or to the still potent spirits of mountain, river, or spring.

We have almost exhausted our space in discussing the important problems raised in the NO. 24I2, voL. 96] introductory chapter, in which the learning, acumen, and wit of the author are conspicious. The material on dance and drama among barbaric and savage races is of the highest value, and must be studied by all future historians of the stage. The facts from India, due to help received from Sir John Marshall and the staff of the Archæological Survey, are of special interest, and the fine collection of photographs taken for this work is admirable. Two of the illustrations are here given, by the courtesy of the publishers. When we are told that the Shiah form of Islam is dominant in India, it may be pointed out that though this sect is more active and fanatical than that of its rivals, the Sunnis, the latter holds a decided numerical superiority. It is to be regretted that the proofs of the chapter on Hindustan were not read by a competent Oriental scholar, who would have been able to detect some irritating perversions of names which detract from the scientific accuracy of the work.

\section{THE METRIC SYSTEM AND DECIMAL COINAGE.}

THERE are probably few readers of NATURE who do not realise that what is being referred to in the Press as "The War after the War" is nothing more than a tardy appreciation of the "war before the war" which Germany has been waging against England for a quarter to half a century in the applications of science to commerce. It has been stated over and over again that German firms have been ousting British trade in many countries by issuing price lists containing quotations in the metric system of weights and measures. A further element of success has been that the enterprising Germans have in many cases told prospective purchasers the exact amount of money in their own currency which they would have to pay in order to have the goods delivered at their house, free of carriage, customs dues, or all other charges.

Now scientific men have been preaching the adoption of the metric system for years. The advantages which this country would gain by discarding British weights and measures, and using those which have now become international, are well known to every thinking man. In these circumstances it must be regarded as regrettable that the Electrical Review, in a series of articles entitled "Decimal Coinage and the Metric System" (October I 5 to November 26), has associated these undoubted claims for standardisation of units with the advocacy of a change of monetary system which nobody understands, and which does not appear calculated to advance the cause of international uniformity. 
The editor of the journal in question circulated among business firms about $45^{\circ}$ copies of a letter, to which more than 120 replies were received. The following questions were asked of the recipients of the letter :-

I. Do you employ the metric system in your correspondence with foreign clients?

2. Are your products

(a) described in your catalogues in terms of metric weights and measures?

(b) priced in terms of foreign coinage?

3. Do you employ the metric system in your workshops?

4. Are you in favour of the adoption in this country (a) of decimal coinage?

(b) of metric weights and measures?

5. May we quote your name in referring to your replies in the Electrical Review?

The result has been a very thorough discussion of the advantages of the metric system, and the absence of any substantial evidence regarding the monetary question. Many firms are actually using metric units; in electrical, physical, and chemical work they have become universally recognised, and in cases where they are not exclusively adopted they are at least used in foreign trade. On the other hand, few firms are able to give quotations in foreign currency, owing to the varieties of foreign coinage and the fluctuations of the rate of exchange. Where manufacturers have expressed themselves favourably to decimal coinage their replies strike us as not being based on any substantial grounds.

In examining this aspect of the subject the questions which naturally arise are:-(r) What is meant by decimal coinage? (2) What countries have adopted it? (3) What is the system it is proposed to adopt here?

Now the decimal system of weights and measures which is in international use is based on a distinctive and unique nomenclature for tens, hundreds, thousands, and the corresponding submultiples of the fundamental unit, whether it be a unit of length, capacity, or weight. By a process of natural selection those multiples and submultiples have been retained which have been found most useful; for example, millimetres, centimetres, metres, and kilometres, to the exclusion of other derived units. But no country in the world has adopted a decimal coinage based on this nomenclature. Instead of this we have a perfect chaos of centesimal systems, each based on the subdivision of a fundamental unit into a hundred "cents." In most cases, sums of money amounting to millions of pounds are expressed in terms of a unit no larger than a shilling, while sums less than a shilling are expressed in tenths of a penny, although coins of less than five-tenths are rarely used. In some cases $\frac{23}{100}$ of the larger unit is commonly used in preference to the $\frac{1}{10 \pi}$.

The plea for a decimal coinage must therefore either be an advocacy, not of a decimal system, but of a centesimal system similar to one actually in use, or it must represent a demand for something new and different.

Now the disadvantages of uniformity will be NO. 24 I 2 , VOL. 96] evident to anyone who travels in one of the countries of the so-called Latin Union, such as France, Switzerland, Italy. It is often quite impossible to obtain change for a sovereign in the current coin of the realm. Instead the traveller receives a collection of coins of a number of different countries, some of them good, others bad. The only countries in which bad money can never circulate are those, such as Germany and Austria, which have distinct monetary units. If England were to adopt the franc and centime, England would soon be flooded with foreign money. The difficulty of deciding, by means of diagrams, whether a particular coin is good or bad is at least equal to the difficulty of reducing shillings to pence, and most inhabitants of the countries in question have accumulations of bad money that they are only too glad to pass off on an uninitiated Englishman.

If, however, the system is to be different from those of other countries, it is difficult to see how it can facilitate foreign commerce. The exchange value of an English sovereign is well known all over the world, and quotations in pounds are fully understood. The only difficulty may arise among foreign clients with the twelve pence in the shilling. But in foreign trade pence practically never enter into the calculations, and all that the manufacturers need do is to give their quotations in decimals of a pound, which they can easily do.

It is in the last of the series of articles that the contributor of the Electrical Review gives himself away. After obtaining overwhelming evidence of the advantages of the metric system, he proposes that the coinage should be changed first, and that the remaining changes should follow within a time-limit of one twelvemonth. It would appear that the proposed coinage should leave the pound and the shilling intact, and should depreciate the value of the penny by about 4 per cent.

We need not have any serious apprehensions that Parliament would ever consent to a proposal which would rob the working-man of a fraction of the value of his penny while leaving the incometax payer unmulcted. It is, however, fairly evident that if such a scheme were adopted penny articles would not be sold for less than a penny farthing, and we should thus approximate to the system of marks and pfennige of Germany.

The writer of the present article happened to be travelling in Austria a little while after the change from gulden and kreuzer to kronen and heller, and although this alteration involved nothing more than doubling the figures, the confusion was very great and the change took a long time to effect.

It is quite clear that any attempt of this kind introduced during the present universal upheaval would lead to a state of chaos in our international trade which would induce our foreign clients to transfer their business to Germany, or to some neutral country with the coinage of which they had become familiar.

In conclusion, whether the attempt to introduce 
decimal coinage be desirable or undesirable, its association with a movement for adopting the metric system can only have the effect of retarding a change for which the time is ripe, and which is necessary in order that Great Britain may hold her own in the world of international commerce.

\section{G. H. B}

\section{NOTES.}

THE recent circular addressed to the dealers in platinum by the Director of Materials in the Ministry of Munitions requiring them to make a return of the whole of the stock of this metal, its ores and residues, on their premises, and forbidding any trading without a permit under a heavy penalty, will cause no surprise to those scientific men who are cognisant of the situation. Indeed, it is to be regretted that this step has not been taken before. It is most unfortunate that this rare, and for many purposes indispensable, metal has been allowed to be used for jewelry and purely ornamental purposes. Either silver or gold is much better adapted to the production of attractive ornaments and is more beautiful than the greyishwhite of platinum, while, of course, neither has the high melting point, electrical resistance, and chemical refractory qualities which make platinum so valuable a metal both in science and in the arts. The normal annual world's output of this metal is about 300,000 troy ounces. This figure dropped in I9I4 to 250,000 ounces in consequence of the outbreak of war. Russia produces 95 per cent. of the world's total, chiefly from the Ural placers. The crude platinum contains from 7o to go per cent. of this metal, but it is invariably alloyed with iron in considerable proportions and with varying amounts of the other metals of the platinum group. Colombia produces about ro,00o ounces, while the total output of other countries does not exceed 2000 ounces. It is abtained in the United States Mint in the electrolytic refining of gold and silver, but only in amounts of about 200 ounces per annum. A small amount is also recovered from the mud resulting from the electrolytic refining of copper. Considerable interest was aroused by the recent announcement that platinum had been discovered in the Lower Rhine region of Germany. No statements as to its possible commercial exploitation have as yet been forthcoming.

SINCE the outbreak of war, the research institutes and stations aided by the Board of Agriculture under the Development Act scheme have been fulfilling useful functions. The new conditions have given rise to many new problems, chiefly in regard to the use of new feeding stuffs and the supply of artificial manures. In relation to the former, the blockade of Germany's imports has led to the appearance on the home markets of a number of oil-seed residues, such as palm-nut kernel, coconut, etc, in regard to the use of which as feeding stuffs little precise information was available; again, the scarcity and dearness of some of the other better known materials have necessitated the use of substitutes, and it has become important to supply agriculturists with advice on the making up of rations containing unfamiliar mixtures

$$
\text { NO. 24I2, VOL. 96] }
$$

of ingredients. The Institute of Animal Nutrition at Cambridge has given valuable aid in this direction, and the monthly notes which it contributes to the Journal of the Board of Agriculture contain information which has been much appreciated by farmers.

THE utilisation of peat, whether as a source of power, for use in the manufacture of explosives, or as the basis of a manure, is attracting much attention at present, and the subject is naturally one in which the Rothamsted Experimental Station is in a position to undertake useful work. At the request of the Board of Agriculture, the station has recently undertaken to make a complete investigation of the claims made in regard to Prof. Bottomley's bacterised peat or "humogen," the nature and properties of which were described in Nature of December 9, I9I5 (p. 399). As they have been stated in the daily Press, these claims appear to be threefold: first, that the substance contains an accessory food substance; secondly, that it supplies soluble humus; and, thirdly, that its nitrogen content is higher than that of most organic manures. The first claim-the presence of an accessory food substance-is the one that will attract most attention, for if it can be substantiated it will not only constitute a distinct scientific advance, but will make the economic problems involved much simpler. "Humus," after all, is the cheapest manure, and it is not likely that for ordinary agricultural crops any manufactured product will be able to compete with such a cheap source as the farm manure-heap. The investigation at Rothamsted will include an examination of the processes by which humogen is manufactured, as well as trials on a field scale under carefully controlled conditions.

Mr. Tennant stated in the House of Commons a few days ago that from the beginning of hostilities to November last, I365 cases of enteric (typhoid) fever were reported as having occurred among British troops in France and Belgium. Of these, i 150 had been diagnosed after bacteriological examination. In $\mathbf{5 7 9}$ cases where there had been inoculation there were 35 deaths, and in $57 \mathrm{I}$ cases where there had been no inoculation there were I 5 deaths. We hope that Mr. Tennant's statement will put a stop to the last trace of opposition to the protective treatment against typhoid fever. We do not say that the method is perfect; but we do say that it protects our soldiers from dying of typhoid fever. The figures given by $\mathrm{Mr}$. Tennant are absolutely final; the method, in years to come, may be improved; but the good which it has achieved is past all possibility of sane doubt. Happily, the opposition never came to much, and now is coming to an end. It has had one good effect on the public mind: it has helped to destroy the influence of the "anti-vivisectionists" and the "anti-vaccinationists." These two bodies, never far apart, made common cause against the work of protecting our soldiers against the horror of death from typhoid fever. Among the "anti" assertions, we may note the statement that typhoid and paratyphoid are so like each other that the figures for typhoid are worthless. This assertion is untrue. Even if we add the paratyphoid cases to the typhoid 